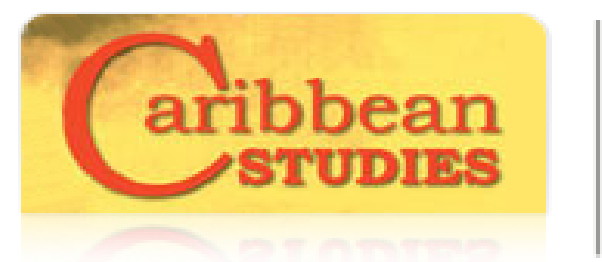

\section{Caribbean Studies}

ISSN: 0008-6533

iec.ics@upr.edu

Instituto de Estudios del Caribe

Puerto Rico

Colón Warren, Alice

WOMEN'S EMPLOYMENT AND CHANGING GENDER RELATIONS IN PUERTO RICO

Caribbean Studies, vol. 38, núm. 2, julio-diciembre, 2010, pp. 59-91

Instituto de Estudios del Caribe

San Juan, Puerto Rico

Available in: http://www.redalyc.org/articulo.oa?id=39222626004

How to cite

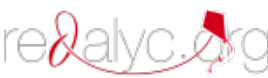

- Complete issue

- More information about this article

Journal's homepage in redalyc.org

Scientific Information System Network of Scientific Journals from Latin America, the Caribbean, Spain and Portugal Non-profit academic project, developed under the open access initiative 


\title{
WOMEN'S EMPLOYMENT AND CHANGING GENDER RELATIONS IN PUERTO RICO
}

\author{
Alice Colón Warren
}

\begin{abstract}
This article discusses Helen Safa's analyses of the impact of development strategies and social policies on gender relations and women headed families in the Caribbean and Puerto Rico. The discussion focuses on findings of a research project regarding patterns of women's employment, autonomy, marital relations, family headship and poverty in Puerto Rico in the decade beginning in the year 2000, using excerpts from interviews conducted with women workers displaced from a clothing and a tuna factory between 2001 and 2002 (Colón et al. 2008), as well as data from the Public Use Sample (PUMS) of the U.S. Census Puerto Rico Community Survey 2005-2007. It is argued that women's employment has resulted in advances in women's autonomy, gender equity, and renegotiations of the provider role, but, intensified by men's unstable earnings, it has also led to the increase of female family headship even among married women. Women's education and employment have been an important means of reducing family poverty both among dual earner families and female heads. Yet, the continuing joblessness in the Island places even higher educated sectors on the verge of economic precariousness.
\end{abstract}

Keywords: Puerto Rico, women's employment, gender relations, female-headed families, Helen I. Safa

\section{RESUMEN}

El artículo discute los análisis de Helen Safa en torno al impacto de las estrategias de desarrollo y las políticas sociales sobre las relaciones de género y las familias con jefa mujer en el Caribe y Puerto Rico. La discusión incorpora los hallazgos de una investigación acerca de las tendencias en el empleo de las mujeres, su autonomía, las relaciones maritales, la jefatura de familia femenina y la pobreza en Puerto Rico en la década que comenzara en el 2000. Se utilizaron extractos de entrevistas a mujeres obreras desplazadas de la industria de la ropa y atunera entre el 2001 y 2002 (Colón et al. 2008) y los datos de la muestra de uso público de la Encuesta de la Comunidad del Censo de Estados Unidos en Puerto Rico 2005-2007. El artículo argumenta que el empleo de las mujeres ha propiciado avances en la autonomía de las mujeres, la equidad de género y renegociaciones en el rol de proveedor, pero que intensificado por la inestabilidad en los ingresos masculinos, también 
ha resultado en el incremento de mujeres jefas de familia, incluso entre mujeres casadas. La educación y el empleo de las mujeres son medios importantes para reducir la pobreza familiar tanto entre familias donde ambos cónyuges se encuentran empleados, como entre las jefas de familia. Sin embargo, la trayectoria continua de empleo limitado en la Isla hace vulnerables a la precariedad económica aún a los sectores de la población con escolaridad más elevada.

Palabras clave: Puerto Rico, empleo femenino, relaciones de género, mujeres jefas de familia, Helen I. Safa

\section{RÉSUMÉ}

Larticle évalue les études réalisées par Helen Safa sur l'impact des stratégies de développement et les politiques sociales relatives aux rapports de genre et familles dirigées par des femmes dans la Caraïbe et à Porto Rico. Lévaluation tient compte des résultats d'une recherche dirigée vers les tendances de l'emploi des femmes, leur autonomie, les relations conjugales, la responsabilité des familles féminines et la pauvreté à Porto Rico durant la première décennie de l'année 2000. Des extraits d'entrevues ont été utilisés avec des ouvrières révoquées de l'industrie de vêtements et de vente de thon entre les années 2000 et 2002 (Colón et al. 2008) et des informations de l'échantillon de l'utilisation publique de l'Enquête de la Communauté de Recensement des Etats Unis à Porto Rico 2005-2007. En outre, l'article explique que l'emploi des femmes leur a permis d'être plus autonomes, a avoir plus d'équité de genre et a redéfinir leur rôle de pourvoyeur, à cause de l'instabilité de la contribution masculine. Ainsi, un grand nombre de femmes chefs de famille a été augmenté, y compris des femmes mariées. Léducation et l'emploi des femmes constituent d'importants moyens pour réduire la pauvreté au sein des familles où les conjoints ont l'accès à l'emploi ainsi que celles dirigées par des femmes. Cependant, la trajectoire de cette utilisation qui continue de façon limitée dans l'Iles rend les femmes vulnérables face à la précarité économique même dans les secteurs de la population où les frais de scolarité sont très élevés.

Mots-clés: Porto Rico, emploi féminin, rapports de genre, femmes chefs de famille, Helen I. Safa.

Received: 3 June 2010 Revision received: 6 December 2010 Accepted: 7 December 2010

$\mathrm{H}$

elen Safa's analyses of the impact of development strategies and social policies on gender relations in the Hispanic Antillean Caribbean have been an important and pioneering contribution to research on these topics. This is true not only for the region, but for broader international contexts. A main argument in her work has been that industrialization promoting women's employment 
has contributed to their autonomy in a number of spheres. However, she also shows that these processes have the effect of moving women's subordination to the workplace and the public sphere. Focusing on gender relations and class conflict, she has contended, as well, that when combined with declining male employment these developments may not lead to more democratic gender relations but, instead, to growing domestic and extra-domestic responsibilities for women, to marital conflict, and to increases in female-headed families. The limits to employment and public services imposed by neoliberal regimes have made female heads of household more vulnerable to poverty in places like Puerto Rico, where modernization, urbanization, and many social policies have encouraged the separation of nuclear (male- and female-headed) units from extended families, and the establishment of separate households, all the while weakening kinship networks which have supported femaleheaded households in places like the Dominican Republic (Safa 1995, 1998, 1999, 2005, 2006). I feel grateful for Safa's encouragement and inspiration-including her motivation to do research on the conditions imposed by the displacement of workers in labor intensive manufacturing throughout the past decade in Puerto Rico-to continue to do research along parallel lines.

In this article I discuss some findings of a research project regarding patterns of women's employment, autonomy, marital relations, family headship and poverty in Puerto Rico in the decade beginning in the year 2000. While family headship may not be the best way to conceive of intra-family relations, and the idea is biased by cultural expectations that tend to ascribe headship to men, the concept still allows us to highlight the conditions under which women who have taken over their home's economic responsibility live. It also allows us to consider the diversity among female householders (Safa 1998, 1999, 2005, 2006; Chant 2007). For evidence, I use excerpts from interviews conducted with women workers displaced from a clothing and a tuna factory between 2001 and 2002 (Colón et al. 2008), ${ }^{1}$ as well as data from the Public Use Sample (PUMS) of the U. S. Census Puerto Rico Community Survey 2005-2007 (United States Bureau of the Census, Puerto Rico Community Survey, 2005-2007).

\section{A Trajectory of Endemic Joblessness}

The economic crises hitting Puerto Rico in the decade beginning in 2000 was only the latest episode in what was an endemic problem of joblessness throughout the twentieth century. Puerto Rico's post-war industrialization strategy started losing competitive advantages for labor in intensive manufacturing by the late 1960s, and as the United States 
further opened itself to trade agreements with other countries offering even lower wages in the 1980s. By the 1990s, the gradual loss of the remaining U.S. corporate tax incentives in the Island promoting high tech and financial industries, neoliberal trends of industrial restructuring and privatization, and the fiscal and economic crises throughout the decade beginning in 2000, again intensified unemployment (Dietz 2003; Junta de Planificación, 2000). If economic activity throughout most of the twentieth century had declined mainly among men of lesser education levels, job losses started adversely affecting women of lesser education levels, as well as male and female workers in occupations requiring higher education.

Men's employment continued declining from 63 percent of working age males in 1970 to less than half of those of working age in 2009. Women's employment, which had increased, if moderately, throughout the century, rose to around 25 percent in the 1970 and 1980s, remaining stagnant at around one third of working age females since the 1990s up to 2009 (Bureau of Labor Statistics 2007, 2009). Lower-educated men and women were most affected by declining employment during the decade starting in 2000. This era saw the virtual end of the remaining garment production and other labor-intensive manufacturing endeavors on the Island that had contributed substantially to women's employment in the 1950s. There was also the decline of the construction industries that had required lower-educated men's labor. The unemployment rate for men with less than a high school education increased from 13 to 18 percent between 1970 and 2006, reaching 22 percent by 2009. The unemployment rate for women with less than a high school education, which was 10 percent in 1970, increased to 17 percent in 2006 and 28 percent in 2009. Yet, it is significant that the Island also began to experience the loss of jobs in high tech industries and in the public sector-areas that provided employment for higher-educated workers. Unemployment rates for men and women with some university education, which had been minimal in 1970, reached 10 percent for women and 12 percent for men by 2009 (Puerto Rico Bureau of Labor Statistics 2007, 2009) and was due to increase as a result of government measures aimed at further trimming of employment in the public sector after that date.

\section{Women's Employment and Autonomy}

The decline of men's employment and the resulting need for women's economic contribution for personal and family subsistence has reinforced the breakdown of the "myth of the male breadwinner" (Safa 1995). Safa has indeed been insightful in suggesting how the sexual division of labor and women's roles have changed to include the expecta- 
tion of female employment. Among the younger women displaced from labor-intensive manufacturing between 2001 and 2002, their availability for work was taken for granted, and even among the middle aged and older women there was a sense that their "helping out" in family expenses was actually their obligation:

Mi sueldo estaba dispuesto ahí para lo que hacía falta... yo sabía que tenía un deber de ayudarlo.

[My wage was there for whatever was necessary... I knew that it was my duty to help him]

Para eso trabajé, porque antes el único que trabajaba aquí era él. Necesitaba y tenía que ayudarlo...

[That is why I became employed, because before he was the only one working here. I needed to and I had to help him...] (quoted in Colón et al. 2008).

It has meant a movement from their definition exclusively as housewives, to the later acceptance of the two-earner family, blurring some aspects of the socially defined separation of spheres and providing for more democratic gender relations.

Studies documenting Puerto Rico's modernizing processes suggest how women's access to independent earnings and education, among other social and juridical trends promoting women's rights, tended to erode patriarchal family patterns in which men controlled female movement and their work out of the household (Steward et al. 1956; Stycos 1955; Brameld 1959; Tumin and Feldman 1961; De Roca 1963; Crespo Kebler 1994; Colón Warren 2002). Safa documents the changes in women's status among women garment workers and those whose access to public housing and services provided them with more independent resources, contributing to an increasing sphere of women's autonomy, even if not breaking with female subordination and their definition as central family figures (Safa 1974, 1995; Pérez Herrans, 1996; Muñoz Vázquez y Fernández Bauzó 1988). If not the only determinant, a trajectory of growing female employment has, therefore, been a factor in changing visions regarding women's roles, leading to their greater participation in the public sphere, child bearing, fertility control, and family budgets, and their rejection of the more open expressions of men's authoritarianism and control, unfaithfulness or violence (Safa 1995; Muñoz Vázquez and Fernández Bauzó 1988).

Echoing women workers' voices from early on in the Island's process of industrialization (Reynolds and Gregory 1965), the women displaced from the clothing and tuna factories in 2001-2002 whom I studied in a collaborative research project commented on their sense of autonomy and self worth, as well as their social participation beyond the domestic 
sphere as aspects which they greatly missed from their work experience:

$A$ veces no es lo mismo tener dinero de uno que esperar a que el esposo cubra... Por lo menos ahora yo me he acostumbrado a tener mi propio dinero. Si yo necesitaba algo tenía los chavos ahí, eran míos.

[Sometimes it is not the same to have your own money than waiting for your husband to cover it... At least now I have become used to have my own money. So if I needed something I had the money there, it was mine.]

Porque en sí a uno le hace falta como independizarse, no estar pendiente de que a uno le den, iqué sé yo!

[Because one needs like to be independent, not waiting for someone to give things to you, I don't know!] (Colón et al. 2008).

These women valued the social relations they shared at the workplace, contrasting it with the isolation they found in the household, through repeated phrases like: "En el trabajo era diferente, hablando desde que llegaba" [It was different at work, one was talking from the moment you came in]; "conoces personas" [you meet people]; "extrañar los compañeros" [missing friends], "era como una familia" [it was like a family], or considering it even "therapy." These women workers recognized the personal worth and broadened social representation they had enjoyed with their work outside the household and how these gains could be relinquished as they returned to full-time domesticity and economic dependency. Indeed, the demise of labor-intensive manufacturing and declining jobs for lower-educated women may threaten movement towards greater equity between couples that women's employment and all that it entailed was able to facilitate.

\section{Marital Conflict and Female-Headed Families}

Safa $(1995,1998,1999,2005,2006)$ has contextualized such potential equity in relations focusing not only on women's status but on the status of men and on gender relations. Women's employment and improving social status may lead to more democratic marital relations, but it can also accentuate marital conflict and dissolution if men are unwilling to relinquish their privileges in the family (Tumin and Feldman 1961; Stycos 1955). Safa $(1995,1998,1999,2005,2006)$ highlights how conflict may be precipitated particularly with declining male employment, even if the man's unemployment is not the direct cause of marital dissolution. Erosion of a man's power as main provider may not only make individual men seem "irresponsible," but may make the authoritarian relations appear more unreasonable and women less accepting of what they deem to be an unsatisfactory relationship. Although perhaps by attributing 
the conflict to the particular man's individual behavior and not overtly questioning the structures that still provide for male social and sexual privileges, women resist practices of gender inequality through separation, divorce and avoiding remarriage (Muñoz Vázquez and Fernández Bauzó 1988). This situation may also make women appear as more "demanding," and actually put pressure on men to demonstrate their control through other expressions of domination, or detach them from family responsibilities and established male roles (Safa, 1995, 1999, 2006; Stycos 1955; Seda Bonilla 1958; Román and M. López 1987).

Women's ascribed childrearing and domestic roles have made them liable to be regarded as family heads when faced with marital conflict and dissolution (Colón Warren 2006). Considering such definitions of women's domestic responsibilities, Safa $(1998,1999,2005,2006)$ has analyzed how in the Caribbean female-headed households are but an alternative form of family organization in which consanguineal ties, particularly through the mother's line, have historically been reinforced and have even taken precedence over the conjugal bond, given more "unstable" marital relations. This type of family has increased in the context of conflicting relations of gender inequality and of economic conditions that make men less able or willing to support their families. If the conjugal bond and legal marriage have been more institutionally and legally promoted in Puerto Rico, high divorce rates and increasing female headed families in the Island suggest patterns in some way following the more general trend in the non Hispanic Caribbean. ${ }^{2}$

Dimensions of socioeconomic inequality impinge on expressions of marital conflict and gender relations. Safa $(1974,1995)$ found the most egalitarian relations among younger couples living in more middle-class environments and where both women and men were securely employed and better educated. Economic and social constraints may intensify conflicts related to gender inequality if, with fewer additional sources of displaying power in society, men in these social strata resort to more open authoritarian behavior while being less capable or willing to fulfill the role of economic provider (Muñoz Vázquez and Fernández Bauzó 1988). Women of lower strata may thus be more subjected to unsatisfactory relations and be less moved by status considerations to remain in them, providing for divorce and separation.

One of the women displaced from factory jobs expressed how her husband's economic "irresponsibility" enhanced her resistance to his infidelity, leading to their divorce.

Ese es el daño que uno se hace a veces... Porque a veces las responsabilidades las lleva uno, me entiendes. No todos los hombres son iguales, te dejan la carga... Mi papá siempre me decía: 'No trabajes, que el hombre es el que trabaja,' pero ... (no fue así)... después se enamoró... 
[That is the harm one does to oneself sometimes... Because sometimes ones takes over the responsibilities, you know. Not all men are the same, they leave you with the burden... My father always said: 'Don't work, it is the man who should work,' but ... (it was not like that) ... then he fell in love...].

Women's education and employment have in fact been popularly acknowledged as means not to be forced into oppressive relations by economic dependency (Crespo Kebler 1994). The factory job, for example, had been a means of one of the displaced workers to gain the strength and capacity to leave an abusive relation, where she was subjected to violence and economic exploitation. As she said:

Puedo hacerlo sola... Esto no me conviene, alquilé esta casa, lo dejé todo... (Antes) Era una persona indecisa, tenía miedo a hacer las cosas, miedo a echar pa'lante sola... (pero) no he necesitado nada de él... (Yo) era bien tímida... Empecé a ser libre, y ahora me siento mejor... Trabajar en la fábrica me sirvió de experiencia para saber que es mejor tener algo de uno...

[I can do it alone... This is not good for me, I rented a house, I left everything... (Before) I was an insecure person, I was afraid of doing things, afraid of going on alone... (But) I have not needed anything from him... (I) was very shy... I began being free, and now I feel better... Working in the factory provided me with the experience to learn that it is better to have something of your own...]

In this respect, if we may expect trends of female headship to grow with women's increasing education and occupational opportunities (Safa 2005), these could not be limited to those in lower status, but may become more prevalent among those in higher socioeconomic strata. Women of lower strata may actually be more vulnerable to male control and violence if they don't have the material, social, and personal resources to confront the violence and may be more pressured to remain with partners out of economic need. The decline in female jobs may increase their dependency and restrain their possibilities to become family heads.

Just as well, female family headship may not be limited to women without a husband present. Our study (Colón et al. 2008) of displaced workers confirmed that women's economic contribution has become an expectation not only among themselves, but among men. Under conditions of male unemployment and the expectation of women's economic contribution, the distribution of payment for household needs may become another area of marital contention and negotiation. One displaced garment worker told us about her negotiations sharing expenses with a husband who did not contribute economically even after he was already employed: 
Pero después que mi esposo empezó a trabajar pues él pensaba que yo iba a seguir pagando todo, tú sabes, se acostumbró a que yo pagase todo. $Y$ hasta que un día yo vine enfogoná de trabajar.. y él llegó y yo le dije: bueno, te voy a decir una cosa, ya tú tienes trabajo, ya tú estás ganando bueno... Aquí está el ticket (la factura) del agua... aquí está el de la luz... y la mitad de la compra la pones tú y la mitad yo... Porque mija a veces los hombres se quedan (esperando que) ella lo hace todo, ella lo hace todo, y uno tiene que hacer de tripas corazones.

[But after my husband started working he thought that I would go on paying everything, you know, he got used to me paying everything. Until one day when I came angry from work... and he arrived and I told him: look I am going to tell you something, you already have a job, you are already having good earnings... Here is the water (bill), here is the electricity... and half of the food you buy and half I will pay... Because sometimes men keep (expecting that) she will do everything, she does everything, and one has to make ends meet.]

Among the displaced women in our study, their contribution was assumed as a necessary adjustment to maintain family livelihood, allowing for the renegotiation of their marital relations. Besides providing for a more comfortable economic position when both were employed, among these women it was accepted as natural that they would share and take over household expenses when it was necessary, particularly when the husband was not employed. Some of them emphasized how each was expected to pay depending on who had the money at the moment:

Cuando él no podía, pagaba yo. Si él tenía más, como yo no tenía, él pagaba... Todo es para lo mismo, cuando él no tenía yo le daba, cuando yo no tenía, él me daba.

[When he could not do it I would pay. If he had more, since I did not have it, he paid... It is all the same, when he did not have money I gave it to him, when I did not have it, he gave it to me].

Women may even surpass their partner's earnings, as commented by some of the displaced tuna factory workers:

Yo llegué allí porque quería prosperar. A mi esposo no le gustaba que trabajara fuera del hogar, pero como él se quedó sin trabajo, me dejó por tres meses buscar trabajo y me quedé hasta el final, llegué a ser supervisora... como ganaba más que mi esposo compartíamos los gastos, entre los dos.

[I went there because I wanted to be better off. My husband did not like my working out of the household, but since he was left without a job, he allowed me to look for work for three months and I stayed until the end, I became a supervisor... since I earned more than my husband, we shared expenses, between the two of us].

Women's employment may thus lead to rearrangements and even inversions in the provider role, becoming main earners and de facto 
female heads even among married couples, at least at some points of their relationship. We must, therefore, also highlight, that although most of our research on female headed families has focused on those women living without a husband present in the household, we must also consider the presence of married women who could also appear as providers in a situation of what may be considered de facto female headship or at the least joint headship. Again, the loss of female job opportunities renders these rearrangements and negotiations less possible.

\section{Marital Status, Education, and Paths to Female Household Headship}

We have observed how conditions challenging the male provider role and tending towards marital dissolution may be more frequent in lower socioeconomic strata. Still, the presence of female heads may be as likely in higher strata if women with greater economic resources also tend to resist unequal and unsatisfactory relations and are even more capable of maintaining their own households. Safa has also noted that the paths to family headship vary by age, stage in the life cycle and marital status, which impinge on their structure of kinship relations (Safa 1995, 1998, 1999, 2005).

Even given its limitations, in this section I use the PUMS of the Puerto Rico Community Survey in the period of 2005-2007 to explore the extent to which men have been relinquishing marriage and their role as family heads, and to try to understand the paths to female household headship as differentiated by educational levels as rough indicators of socioeconomic status (United States Bureau of the Census, Puerto Rico Community Survey 2005-2007). Using census definitions, in what follows I will consider being the householder, that is, the owner or renter of the home, also as a rough indicator of main economic responsibility and of household headship. While PUMS data do not allow us to separate householders who were living alone or with non-relatives from those who are family heads, through a consideration of marital status we will be able to identify divorced and widowed women, more likely to be both household and family heads without a husband present, in relation to the conditions of married and never married women in general and those identified as householders.

In Table I, the 2005-2007 PUMS data show that marriage was the most prevalent status among both men and women over 15 years old, 53 to 44 percent respectively, indicating the prevalence of the conjugal bond as an institution, and of the married couple family as the basis for material, social and personal reproduction in Puerto Rican society. Nonetheless, being married is indeed somewhat more frequent among 


\section{Table I - Gender By Marital Status And Education (Persons 16 Years And Over) 2005-2007 (Per Cent/Numbers In Parentheses)}

\begin{tabular}{|l|c|c|c|c|c|c|c|c|}
\hline \multirow{4}{*}{} & \multicolumn{5}{|c|}{ WOMEN } & \multicolumn{4}{c|}{ MEN } \\
\cline { 2 - 9 } & $<$ HS & HS & $>$ HS & Total & $<$ HS & HS & $>$ HS & Total \\
\hline \multirow{3}{*}{ Married } & 40 & 47 & 46 & 44 & 48 & 54 & 56 & 53 \\
\cline { 2 - 10 } & $(6113)$ & $(4834)$ & $(8897)$ & $(19844)$ & $(6912)$ & $(5278)$ & $(7654)$ & $(19844)$ \\
\hline \multirow{2}{*}{ Widowed } & 24 & 9 & 5 & 13 & 6 & 3 & 2 & 3 \\
\cline { 2 - 10 } & $(3735)$ & $(930)$ & $(1039)$ & $(5704)$ & $(835)$ & $(248)$ & $(207)$ & $(1290)$ \\
\hline \multirow{3}{*}{ Divorced } & 10 & 14 & 16 & 13 & 8 & 10 & 9 & 9 \\
\cline { 2 - 10 } & $(1482)$ & $(1446)$ & $(3087)$ & $(6015)$ & $(1194)$ & $(939)$ & $(1264)$ & $(3397)$ \\
\hline \multirow{3}{*}{ Separated } & 4 & 5 & 4 & 4 & 3 & 4 & 2 & 3 \\
\cline { 2 - 9 } & $(635)$ & $(489)$ & $(724)$ & $(1848)$ & $(484)$ & $(356)$ & $(289)$ & $(1129)$ \\
\hline $\begin{array}{l}\text { Never } \\
\text { married }\end{array}$ & 23 & 25 & 29 & 26 & 34 & 31 & 31 & 32 \\
\cline { 2 - 9 } & $(3478)$ & $(2501)$ & $(5522)$ & $(11501)$ & $(4870)$ & $(3044)$ & $(4160)$ & $(12074)$ \\
\hline Total & 100 & 100 & 100 & 100 & 100 & 100 & 100 & 100 \\
\hline N & $(15443)$ & $(10200)$ & $(19269)$ & $(44912)$ & $(14295)$ & $(9865)$ & $(13574)$ & $(37734)$ \\
\hline Source: Public Use Sample of the U.S. Census Puerto Rico Community Survey $2005-2007$. & \\
\hline
\end{tabular}

the higher educated compared particularly to those with less than high school (56 percent among men and 46 percent of women with more than a high school education) suggesting that socioeconomic constraints may impinge on the conditions facilitating marital relations.

Men were more likely to be married than women. Here we see the effects of their social and economic advantages in their search for mates entailing social definitions linking marriage to dominant and positive images of maleness as responsible providers. Nonetheless, they were also more likely than women to be relinquishing this expectation by remaining unmarried, 32 percent compared to 26 percent of women. Although very limited, educational differences in marital status among men did point to a somewhat higher propensity of those with less than a high school education (34 percent) to be unmarried than those with higher education (31 percent), besides slightly more widowers ( 6 percent compared to less than 3 percent among those with High School or over), probably related to the presence of older men among those with lower schooling.

The presence of female heads of household we will be discussing suggests the linkages of kinship and survival reinforced through consanguineal ties and women's responsibility for the family's care and reproduction 
in the context of unstable marital relations. Marriage appears as a less tenable or preferred option among women (Table I), who are still more subjected to unequal treatment in their relations with men. Table II shows that it is women's tendency not to remarry that appears to lead the changes in marital statuses that leave them as female householders. We must note, however, that not all instances of marital dissolution may be attributed directly to marital conflict. As Safa $(1998,2005)$ has also indicated, a notable proportion of female heads over 15 years old in Puerto Rico, 25 percent in 2005-2007 were widows. This is related to the higher female life expectancy and its continuing increase in the Island, although also to the conditions of gender inequality that reduce their propensity to marry: both the preference of men for younger women and the resistance of older women to engage in another marital relation. It is these older women's tendency to have lower schooling that contributes to the higher proportion of female heads among women of lower strata and education. The concentration of widows among female householders with less than a high school education was 44 percent, compared to around one fifth of those with a high school education and 11 percent

\section{Table II - Gender by Marital Status and Education of Householders (16 Years and Over) 2005-2007 (PER CENT/Numbers in Parentheses)}

\begin{tabular}{|l|c|c|c|c|c|c|c|c|}
\hline \multirow{4}{*}{} & \multicolumn{5}{|c|}{ WOMEN } & \multicolumn{4}{c|}{ MEN } \\
\cline { 2 - 9 } & $<$ HS & HS & $>$ HS & Total & $<$ HS & HS & $>$ HS & Total \\
\hline \multirow{2}{*}{ Married } & 21 & 27 & 31 & 26 & 69 & 75 & 76 & 73 \\
\cline { 2 - 10 } & $(1412)$ & $(1070)$ & $(2348)$ & $(4830)$ & $(4765)$ & $(3745)$ & $(5708)$ & $(14218)$ \\
\hline \multirow{2}{*}{ Widowed } & 44 & 19 & 11 & 25 & 9 & 4 & 2 & 5 \\
\cline { 2 - 10 } & $(3017)$ & $(766)$ & $(871)$ & $(4654)$ & $(638)$ & $(199)$ & $(155)$ & $(992)$ \\
\hline \multirow{2}{*}{ Divorced } & 16 & 27 & 31 & 25 & 9 & 9 & 9 & 9 \\
\cline { 2 - 10 } & $(1107)$ & $(1081)$ & $(2381)$ & $(4569)$ & $(616)$ & $(448)$ & $(697)$ & $(1761)$ \\
\hline \multirow{2}{*}{ Separated } & 7 & 9 & 7 & 7 & 3 & 3 & 2 & 2 \\
\cline { 2 - 9 } & $(485)$ & $(349)$ & $(512)$ & $(1346)$ & $(198)$ & $(134)$ & $(135)$ & $(467)$ \\
\hline \multirow{2}{*}{$\begin{array}{l}\text { Never } \\
\text { married }\end{array}$} & 13 & 19 & 20 & 17 & 9 & 9 & 11 & 10 \\
\cline { 2 - 9 } & $(873)$ & $(768)$ & $(1571)$ & $(3212)$ & $(637)$ & $(441)$ & $(864)$ & $(1942)$ \\
\hline Total & 100 & 100 & 100 & 100 & 100 & 100 & 100 & 100 \\
\hline N & $(6894)$ & $(4034)$ & $(7863)$ & $(18611)$ & $(6854)$ & $(4967)$ & $(7559)$ & $(19380)$ \\
\hline Source: Public Use Sample of the U.S. Census Puerto Rico Community Survey 2005-2007. & \\
\hline
\end{tabular}


of those with higher education.

Nonetheless, if the presence of widows contributes to their predominance in lower strata and an observed lower educational level of female householders, the tendency of women heading households is also notable at higher strata, where they are more related to conditions of marital conflict and instability. Female household headship is increasingly related to a higher propensity to divorce and separation (Colón Warren 2006), as is apparent among women of other educational levels, including those younger and less prone to widowhood. Around one fourth of women householders with less than a high school education, and close to 40 percent of both those with at least a high school education, and with higher education, were divorced or separated in the 2005-2007 period. Even when apparently increasing, non-married female householders still represented only around one fifth of women heads of household in general and among those with a high school education and above, less among those with lower education. We suggest, therefore, that even when men's joblessness is more common among lower strata and may enhance conflict and marital ruptures, higher socioeconomic status does not preclude gender inequality, and women with more resources may have more possibilities of resisting conflict and marital ruptures. Divorce and separation, as well as non-marriage, suggesting such resistance to conflicting gender relations, appears just as evident among higher educated women than women with just a high school education.

At the same time, although female headed families are predominantly without a husband present, it is important to also underscore the mentioned trend of married women being de facto main earners at least at some moments of their marital relation, and the probability of their even being householders in a situation of at least joint family headship. Even if we consider the possibility that not all persons identified as householders in the Census may actually be owners or renters of their homes or otherwise the main household economic providers, such identification does convey a measure of important economic responsibility. It is thus significant that PUMS data for 2005-2007 show about a fourth of married women as householders (data not shown) and that married women accounted in turn for about one fourth of female householders (Table II). The fact that married householders were more frequent among the higher educated women (Table II) and that they showed higher employment than wives of householders, or than separated or widowed householders (Table V) suggests that they may in fact be at least an important, if not necessarily the only economic contributors to the home's income: de facto heads or joint heads of family. Men's unstable or, in some cases, lower earnings and women's expected economic contributions have also led to rearrangements in gender relations among 
married couples that have become another path to female household headship.

\section{Female Householders and Poverty}

While the linkage between female headed households and poverty has been qualified for different countries like the Dominican Republic (Safa 1998, 2005, 2006; Chant 2007), it has been confirmed as a tendency in Puerto Rico and other areas (Colón Warren 1998, 2006; Barrow, 1996; Bolles, 1985). More likely to have less resources than men and bearing alone greater economic responsibilities, female householders also share women's unequal status in the labor market that segregate them into lower paid jobs and result in lower earnings at each occupational and educational level. Table III shows women householders were more likely to be poor than male householders irrespective of educational level or employment status. Gender differences and differences among female householders' propensity to poverty, however, varied significantly according to educational strata and employment levels but also with respect to marital status. This, in turn, was related to the kinship support and resources available to women heading households.

Probabilities of employment affecting poverty rates were linked to gender definitions enmeshed with marital status. Still in line with the definition of the male breadwinner, married men and married male householders (Tables III and IV) - those most expected to assume family responsibilities-tended to have the highest employment rates. Table IV shows that married men' employment was 50 percent of those 16 years old and over, followed closely by over 45 percent of divorced and separated men, who are also expected to provide for their families, while only around one third of unmarried men and 13 percent of widowers were employed. Just as well, the tables show that women's employment is lower in marital and household statuses which appear more related to female domestic roles and with a greater likelihood of homes where there are or could be other providers, married women in general (Table IV) and particularly wives of householders, and was extremely low for widowed women and householders (Table V). Tables IV and V further show that separated women, a lower proportion of women over 15 and of female householders, appear in a situation close to married women and wives of householders in terms of employment, suggesting they include a group having left a relation in which they were economically dependent. Never married women over 15 years old probably include those who are younger and still living with relatives, so that in general they show lower employment levels (Table IV). Yet, those who become householders appear to bear greater economic responsibilities, many as family heads, and have 
Women’s Employment and Changing Gender Relations...

Table III - Employment Status and Poverty of Householders 2005-2007 by Employment and Education (PER CENT /Numbers in parentheses)

\begin{tabular}{|c|c|c|c|c|}
\hline & $<\mathrm{HS}$ & HS & $>\mathrm{HS}$ & TOTAL \\
\hline \multicolumn{5}{|c|}{ Employment status (Civilian labor force) } \\
\hline \multicolumn{5}{|l|}{ Total male Householders } \\
\hline Employed & $26(1749)$ & $50(2470)$ & $67(5031)$ & $48(9250)$ \\
\hline Unemployed & $4(298)$ & $4(219)$ & $3(219)$ & $4(746)$ \\
\hline Out of the labor force & $70(4807)$ & $46(2274)$ & $30(2266)$ & $48(9347)$ \\
\hline \multicolumn{5}{|c|}{ Married Male householders } \\
\hline Employed & $27(1297)$ & $51(1915)$ & $68(3880)$ & $50(7092)$ \\
\hline Unemployed & $3(162)$ & $3(124)$ & $2(134)$ & $3(420)$ \\
\hline Out of labor force & $69(3306)$ & $46(1703)$ & $29(1668)$ & $47(6677)$ \\
\hline \multicolumn{5}{|c|}{ Female householders (total) } \\
\hline Employed & $9(611)$ & $28(1140)$ & $55(4253)$ & $32(6004)$ \\
\hline Unemployed & $4(294)$ & 7 (294) & $5(418)$ & $5(1006)$ \\
\hline Out of labor force & $87(5989)$ & $65(2600)$ & $39(3009)$ & $62(11598)$ \\
\hline
\end{tabular}

Poverty status (Proportion below poverty of the numbers and sums in employment and education categories)

\begin{tabular}{|l|r|r|r|r|}
\hline Total male householders & $57(3935)$ & $35(1755)$ & $14(1036)$ & $35(6726)$ \\
\hline Employed & $46(809)$ & $30(743)$ & $9(443)$ & $22(1995)$ \\
\hline Unemployed & $86(255)$ & $72(158)$ & $46(105)$ & $69(518)$ \\
\hline Out of the labor force & $60(2871)$ & $38(854)$ & $22(488)$ & $45(4213)$ \\
\hline Married male householders & $52(2481)$ & $31(1174)$ & $11(624)$ & $30(4279)$ \\
\hline Employed & $44(575)$ & $29(548)$ & $8 \quad(308)$ & $20(1431)$ \\
\hline Unemployed & $82(133)$ & $65(81)$ & $36(48)$ & $62(262)$ \\
\hline Out of labor force & $54(1773)$ & $32(545)$ & $55(268)$ & $39(2586)$ \\
\hline Female householders (total) & $74(5064)$ & $61(2442)$ & $29(2256)$ & $52(9762)$ \\
\hline Employed & $54(330)$ & $44(500)$ & $15(634)$ & $24(1464)$ \\
\hline Unemployed & $91(266)$ & $90(265)$ & $75(312)$ & $84(843)$ \\
\hline Out of labor force & $75(4468)$ & $65(1677)$ & $44(1310)$ & $64(7455)$ \\
\hline
\end{tabular}

Source: Public Use Sample of the U.S. Census Puerto Rico Community Survey 2005-2007. 
Table IV - Employment Rates* by Gender, Marital Status and Education (Persons 16 Years and Over) 2005-2007

\begin{tabular}{|c|c|c|c|c|c|c|c|c|}
\hline & \multicolumn{4}{|c|}{ WOMEN } & \multicolumn{4}{|c|}{ MEN } \\
\hline & $<\mathrm{HS}$ & HS & $>\mathrm{HS}$ & Total & $<\mathrm{HS}$ & HS & $>\mathrm{HS}$ & Total \\
\hline \multirow{2}{*}{ Married } & 9 & 25 & 54 & 33 & 28 & 52 & 68 & 50 \\
\hline & $(521)$ & (1194) & $(4822)$ & (6537) & (1952) & (2755) & (5220) & (9927) \\
\hline \multirow{2}{*}{ Widowed } & 3 & 15 & 25 & 9 & 8 & 18 & 25 & 13 \\
\hline & (106) & (137) & (258) & (501) & (68) & (44) & (52) & (164) \\
\hline \multirow{2}{*}{ Divorced } & 17 & 36 & 60 & 44 & 29 & 49 & 63 & 47 \\
\hline & (251) & $(525)$ & (1853) & (2629) & (351) & (458) & $(800)$ & (1609) \\
\hline \multirow{2}{*}{ Separated } & 15 & 29 & 55 & 35 & 30 & 51 & 61 & 45 \\
\hline & (98) & (144) & (398) & $(640)$ & (146) & (182) & (176) & (504) \\
\hline \multirow{2}{*}{$\begin{array}{l}\text { Never } \\
\text { married }\end{array}$} & 7 & 29 & 51 & 33 & 17 & 40 & 54 & 35 \\
\hline & (246) & (715) & (2807) & (3768) & (819) & (1229) & (2228) & (4276) \\
\hline
\end{tabular}

* Number employed in the civilian labor force in parenthesis divided by the total number in the category shown in Table I.

Source: Public Use Sample of the U.S. Census Puerto Rico Community Survey 2005-2007.

higher employment (Table V). It is divorced women and householders, who are more likely to also head families, that show the highest levels of economic activity at 44 percent of employment (Tables IV, V) .

Given the possibility of access to their husbands' additional earnings and resources, even with their lower economic activity married women's poverty levels shown in Table VI were nonetheless lower than women in other marital statuses within all educational and employment categories. Table VII shows that wives of householders were even less likely to be poor. Married female householders appear to have been less able to share resources with their partners, so that their poverty was higher than that of wives of householders, although lower than that of women householders in other marital statuses (Table VII).

Married women strongly reduce the probability of poverty when they increase the probability of households with more than one earner among married couple families. The 2006-2008 published data of the Puerto Rico Community Survey show that over 40 percent of married couple families had two or more earners, with less than 10 percent living below poverty, compared to 39 percent among those with one earner and over half of those without earners (United States Bureau of the Census, Puerto Rico 
Table V - Employment Status of Female Householders by Marital Status and Wives of Male Householders 16 and Over 2005-2007* (PER CENT /Numbers in parentheses)

\begin{tabular}{|c|c|c|c|c|}
\hline & $<\mathrm{HS}$ & $\mathrm{HS}$ & $>\mathrm{HS}$ & TOTAL \\
\hline \multicolumn{5}{|c|}{ Wives of male householders } \\
\hline Employed & $8(346)$ & 24 (819) & $53(3155)$ & $31(4320)$ \\
\hline Unemployed & $2(78)$ & $4(130)$ & $3(206)$ & $3 \quad(414)$ \\
\hline Out of labor force & $90(3928)$ & $72(2487)$ & $44(2628)$ & 66 (9043) \\
\hline \multicolumn{5}{|c|}{ Female householders (total) } \\
\hline Employed & $9(611)$ & $28(1140)$ & $55(4253)$ & $32(6004)$ \\
\hline Unemployed & $4(294)$ & 7 (294) & 5 (418) & $5(1006)$ \\
\hline Out of labor force & $87(5989)$ & $65(2600)$ & $39(3009)$ & $62(11598)$ \\
\hline \multicolumn{5}{|c|}{ Married female householders } \\
\hline Employed & $10(136)$ & 27 (291) & $59(1373)$ & $37(1800)$ \\
\hline Unemployed & $4 \quad(56)$ & $6 \quad(63)$ & $4(103)$ & $5(222)$ \\
\hline Out of labor force & $86(1220)$ & 67 (716) & $37(871)$ & $58(2807)$ \\
\hline \multicolumn{5}{|c|}{ Widowed female householders } \\
\hline Employed & $3 \quad(96)$ & $15(115)$ & $26 \quad(222)$ & $9(433)$ \\
\hline Unemployed & $1 \quad(27)$ & $3 \quad(21)$ & $2 \quad(17)$ & $1 \quad(65)$ \\
\hline Out of labor force & $96(2894)$ & $82(630)$ & $72(632)$ & $89(4156)$ \\
\hline \multicolumn{5}{|c|}{ Divorced female householders } \\
\hline Employed & $17(194)$ & 36 (389) & $60(1438)$ & $44(2021)$ \\
\hline Unemployed & $6 \quad(63)$ & $7 \quad(71)$ & $6(131)$ & $6(265)$ \\
\hline Out of labor force & $77(850)$ & $57(621)$ & 34 (811) & $50(2282)$ \\
\hline \multicolumn{5}{|c|}{ Separated female householders } \\
\hline Employed & $14(70)$ & $28 \quad(97)$ & $55(281)$ & 33 (448) \\
\hline Unemployed & $9 \quad(45)$ & $11 \quad(38)$ & $9 \quad(48)$ & $10(131)$ \\
\hline Out of labor force & $76(370)$ & 61 (214) & 36 (183) & $57(767)$ \\
\hline \multicolumn{5}{|c|}{ Never married female householders } \\
\hline Employed & $13(115)$ & 32 (248) & 60 (939) & $41(1302)$ \\
\hline Unemployed & $12(103)$ & $13(101)$ & $8(119)$ & $10(323)$ \\
\hline Out of labor force & 75 (655) & 55 (419) & $33(512)$ & $49(1586)$ \\
\hline \multicolumn{5}{|l|}{ * Civilian labor force } \\
\hline \multicolumn{5}{|c|}{ Source: Public Use Sample of the U.S. Census Puerto Rico Community Survey 2005-2007. } \\
\hline
\end{tabular}


Table VI - Employment Status and Poverty by Employment Status by Marital Status and Education of Women

16 and Over 2005-2007

(PER CENT/Number in parentheses)

\begin{tabular}{|c|c|c|c|c|c|c|}
\hline \multicolumn{4}{|c|}{$\begin{array}{l}\text { Employment status by marital status } \\
\text { (Civilian labor force) }\end{array}$} & \multicolumn{3}{|c|}{$\begin{array}{c}\text { Poverty by employment } \\
\text { status* }\end{array}$} \\
\hline & $>\mathrm{HS}$ & HS & $>\mathrm{HS}$ & $<\mathrm{HS}$ & HS & $>\mathrm{HS}$ \\
\hline \multicolumn{7}{|l|}{ Married } \\
\hline \multirow{2}{*}{ Employed } & 9 & 25 & 54 & 30 & 22 & 6 \\
\hline & $(521)$ & (1194) & $(4822)$ & (154) & (261) & (310) \\
\hline \multirow{2}{*}{ Unemployed } & 3 & 5 & 4 & 72 & 64 & 49 \\
\hline & $(161)$ & (232) & (347) & $(116)$ & (149) & (169) \\
\hline \multirow{2}{*}{ Out of labor force } & 89 & 71 & 42 & 56 & 40 & 24 \\
\hline & $(5431)$ & (3408) & $(3727)$ & (3007) & (1369) & (904) \\
\hline \multicolumn{7}{|l|}{ Widowed } \\
\hline \multirow{2}{*}{ Employed } & 3 & 15 & 25 & 42 & 29 & 11 \\
\hline & (106) & (137) & (258) & (44) & (40) & (28) \\
\hline \multirow{2}{*}{ Unemployed } & 1 & 3 & 2 & 89 & 88 & 52 \\
\hline & (35) & (25) & (23) & (31) & (22) & (12) \\
\hline \multirow{2}{*}{ Out of labor force } & 96 & 82 & 73 & 65 & 46 & 32 \\
\hline & (3594) & (768) & $(758)$ & (2327) & (349) & (244) \\
\hline \multicolumn{7}{|l|}{ Divorced } \\
\hline \multirow{2}{*}{ Employed } & 17 & 36 & 60 & 55 & 41 & 15 \\
\hline & (251) & (525) & (1853) & (137) & (214) & (270) \\
\hline \multirow{2}{*}{ Unemployed } & 6 & 7 & 6 & 86 & 91 & 72 \\
\hline & $(87)$ & (102) & (195) & $(75)$ & (93) & (140) \\
\hline \multirow{2}{*}{ Out of labor force } & 77 & 57 & 34 & 76 & 68 & 44 \\
\hline & (1144) & $(819)$ & (1038) & $(863)$ & $(554)$ & (453) \\
\hline \multicolumn{7}{|l|}{ Separated } \\
\hline \multirow{2}{*}{ Employed } & 15 & 29 & 55 & 60 & 52 & 28 \\
\hline & (98) & (144) & (398) & (59) & (75) & (111) \\
\hline \multirow{2}{*}{ Unemployed } & 9 & 12 & 11 & 97 & 91 & 80 \\
\hline & (59) & $(60)$ & (79) & (57) & (93) & (63) \\
\hline \multirow{2}{*}{ Out of labor force } & 75 & 58 & 34 & 87 & 83 & 67 \\
\hline & $(478)$ & (285) & (247) & $(414)$ & (235) & (166) \\
\hline
\end{tabular}




\begin{tabular}{|c|c|c|c|c|c|c|}
\hline \multicolumn{3}{|c|}{$\begin{array}{c}\text { Employment status by marital status } \\
\text { (Civilian labor force) }\end{array}$} & \multicolumn{3}{c|}{$\begin{array}{c}\text { Poverty by employment } \\
\text { status* }\end{array}$} \\
\hline \multirow{2}{*}{ Never married } & HS & > HS & <HS & HS & > HS \\
\hline \multirow{2}{*}{ Employed } & 7 & 29 & 51 & 56 & 41 & 17 \\
\cline { 2 - 8 } & $(246)$ & $(715)$ & $(2807)$ & $(138)$ & $(296)$ & $(482)$ \\
\hline \multirow{2}{*}{ Unemployed } & 9 & 14 & 10 & 84 & 73 & 58 \\
\cline { 2 - 7 } & $(317)$ & $(360)$ & $(563)$ & $(265)$ & $(261)$ & $(320)$ \\
\hline \multirow{2}{*}{ Out of labor force } & 84 & 57 & 39 & 68 & 66 & 47 \\
\cline { 2 - 7 } & $(2915)$ & $(1426)$ & $(2149)$ & $(1978)$ & $(935)$ & $(997)$ \\
\hline * Proportion below poverty of the number in employment category. \\
\hline \\
Source: Public Use Sample of the U.S. Census Puerto Rico Community Survey 2005-2007. \\
\hline
\end{tabular}

Table VII - Poverty Status by Employment Status and Education of Female Householders by Marital Status and Wives of Male Householders 16 and Over 2005-2007 (PER CENT/Numbers in parentheses)*

\begin{tabular}{|c|c|c|c|c|}
\hline & $<\mathrm{HS}$ & HS & $>\mathrm{HS}$ & TOTAL \\
\hline Wives of male householders & $51(2213)$ & $32(1111)$ & $13(775)$ & $30(4099)$ \\
\hline Employed & $28 \quad(97)$ & $17(141)$ & $5(150)$ & $9(388)$ \\
\hline Unemployed & $73 \quad(57)$ & $62 \quad(81)$ & $46 \quad(94)$ & $56 \quad(232)$ \\
\hline Out of labor force & $52(2059)$ & 36 (889) & $20(531)$ & $39(3479)$ \\
\hline Female householders (total) & $74(5064)$ & $61(2442)$ & $29(2256)$ & $52(9762)$ \\
\hline Employed & $54(330)$ & $44(500)$ & $15(634)$ & $24(1464)$ \\
\hline Unemployed & $91 \quad(266)$ & $90 \quad(265)$ & $75 \quad(312)$ & $84(843)$ \\
\hline Out of labor force & $75(4468)$ & $65(1677)$ & $44(1310)$ & $64(7455)$ \\
\hline Married & 62 (879) & $48 \quad(509)$ & $20(463)$ & $38(1851)$ \\
\hline Employed & $34 \quad(46)$ & $32 \quad(92)$ & $9(118)$ & $14 \quad(256)$ \\
\hline Unemployed & $77 \quad(43)$ & $71 \quad(45)$ & $57 \quad(59)$ & 66 (147) \\
\hline Out of labor force & $65(790)$ & $52(372)$ & 33 (286) & $52(1448)$ \\
\hline Widowed & $70(2124)$ & 49 (372) & 28 (245) & $59(2741)$ \\
\hline Employed & $45 \quad(43)$ & $32 \quad(37)$ & $11 \quad(24)$ & $24(104)$ \\
\hline Unemployed & $85 \quad(23)$ & $86 \quad(18)$ & 47 & $75 \quad(49)$ \\
\hline Out of labor force & $71(2058)$ & $50 \quad(317)$ & 34 (213) & 62 (2588) \\
\hline
\end{tabular}




\begin{tabular}{|c|c|c|c|c|}
\hline & $<\mathrm{HS}$ & HS & $>\mathrm{HS}$ & TOTAL \\
\hline Divorced & 78 (859) & 63 (685) & 29 (696) & $49(2240)$ \\
\hline Employed & 60 (116) & 44 (172) & 15 (222) & $25 \quad(510)$ \\
\hline Unemployed & $89 \quad(56)$ & $96 \quad(68)$ & 81 (106) & 87 (230) \\
\hline Out of labor force & 81 (687) & 72 (445) & 45 (368) & $66(1500)$ \\
\hline Separated & 87 (424) & 81 (281) & 52 (267) & 72 (972) \\
\hline Employed & $66 \quad(46)$ & $58 \quad(56)$ & $32 \quad(90)$ & 43 (192) \\
\hline Unemployed & $97 \quad(43)$ & $100 \quad(38)$ & $94 \quad(45)$ & 96 (126) \\
\hline Out of labor force & $91 \quad(335)$ & $87 \quad(187)$ & 72 (132) & 85 (654) \\
\hline Never married & 89 (778) & $77 \quad(595)$ & $37 \quad(585)$ & $61(1958)$ \\
\hline Employed & $69 \quad(79)$ & 58 (143) & $19(180)$ & 31 (402) \\
\hline Unemployed & $98 \quad(101)$ & $95 \quad(96)$ & $79 \quad(94)$ & $90 \quad(291)$ \\
\hline Out of labor force & 91 (598) & $85 \quad(356)$ & 61 (311) & $80(1265)$ \\
\hline \multicolumn{5}{|c|}{ * Proportion below poverty in the employment category, numbers shown in Table IV. } \\
\hline \multicolumn{5}{|c|}{ Source: Public Use Sample of the U.S. Census Puerto Rico Community Survey 2005-2007. } \\
\hline
\end{tabular}

Community Survey 2006-2008, Table S1702). Employed married women, including married female householders, but particularly wives of householders were probably more likely to include these dual earners than other female householders, and showed the lowest poverty rates among women in the diverse marital and household relations (Tables VI, VII). The poverty of married male householders was lower than that of total male householders, also suggesting the probability of wives's resources (Table III). Given their probability of being in dual earner families, the poverty rates of employed wives of householders and to a lesser extent of employed married female householders tended to be similar or lower even to those of married male householders (Tables III, VII).

Access to an additional earner, for example, was crucial in maintaining the livelihood of married women facing their husbands' unemployment and their own displacement. By the same token, particularly among younger, higher educated women displaced from the garment industry, their partner's employment allowed them more time to look for a job without facing a more precarious economic condition. One of these workers mentioned:

Porque yo había dicho que yo iba a descansar por un año, y cuando se cumpliera el año, pues ya estaba bueno de vacaciones.

[Because I said that I was going to rest for a year, and when the year 
was over, it was enough of a vacation].

Pressured by the presence of children, but also given their higher schooling and a stronger sense of female employment as an expectation in women of their generation, these women were also more likely to be employed and contributing to the family income by the time we finished our study, albeit underemployed in jobs that did not offer them the earnings or stability in the factory.

The employment trends have made the possibility of these dual earner conditions more difficult, affecting particularly lower-educated men and women. Tables IV and V show that while over half of married women and of wives of householders with higher education were employed, only about one fourth of those with a high school education and less than 10 percent of those with lower education had a job in the 2005-2007 period. Table VII indicates how the rates of their poverty follow suit: from 13 percent among those wives of householders with higher education, to about one third among those with a high school education and over half of those with lower education. Poverty increases among those with lower education even among employed married women (Table VI) and wives of householders (Table VII), suggesting not only their allocation in lower paid jobs, but that their partners' resources and employment are also limited. The economic sharing and well being that may facilitate more equitable and stable intimate partner relations is still limited and concentrated among the higher educated strata. The displacement of even higher-educated men and women is likely to pressure even couples of higher socioeconomic status.

Employment, resources, and poverty among female householders without a husband present also differed according to the women's marital status and education. Widows, who tend to be older and less educated, include women who lived in historical periods of lower female labor force participation as well as those already retired or even displaced from declining lower-skilled jobs. They thus showed only a 9 percent employment rate, ranging from 3 percent for those with less than a high school education to a fourth of those with more than a high school education completed (Tables IV, V). More likely to be advanced in their life-cycle, however, widows may also be less pressured by family economic responsibilities and have the support of their deceased husband's resources, if not those of adult sons or daughters. Divorced householders' poverty was lower (49 percent) than the 60 percent among widows (Table VII), but this was related to their higher employment (Tables IV, V). Even with low employment levels, however, widowed householders showed similar poverty to unmarried householders and lower poverty levels than the 72 percent of those who were separated (Table VII). Widowed 
householders appeared even less prone to poverty when considering differences in employment and education among householders in different marital statuses.

Women householders' employment tended to be higher than wives' among those more likely to be family heads and bearing more pressing economic responsibilities, particularly divorced and never married women. These female householders showed employment rates surpassing 40 percent, ranging from less than 20 percent among those with less than a high school education (13 percent among the never married) and around one third of those who had completed high school, to 60 percent for those whose education had gone beyond high school (Table V). Unmarried female householders, however, seemed more vulnerable to poverty, even when employed. PUMS data (not shown) suggest that a somewhat higher proportion of divorced than unmarried women householders are older, thus having the possibility of a longer work experience, and of holding more stable or higher-status jobs. Age and experience may allow not only for more accumulated assets, but also for a greater probability of sharing the resources of working age sons and daughters. The economic pressures for an older divorced female head of household displaced from the garment factory, for example, were ameliorated by having been promoted to higher paying positions. This allowed her to pay her for her home and for other needs, and given her age, by the possibility of receiving Social Security and, also, by the contribution of an adult son living with his kids in her home, although she continued paying for the maintenance of the household (Colón et al. 2008).

Actually, more important than differences in marital status, poverty reduction in Puerto Rico is highly related to being employed (Sotomayor 1998, 2002; Colón Warren 2006), more probable among workers with higher education. Table III shows how poverty rates were reduced among employed householders, who increased among those with higher education. Male householders' employment increased from 26 percent among those with less than a high school education to two thirds among those with more than a high school education, while their poverty declined from 57 percent to 14 percent respectively. If female-headed households were not disproportionately concentrated among women of lower strata, women with lower schooling did show significantly higher poverty rates than those with higher education, given their lower probabilities of employment. Employment increased from less than 10 percent among women householders with less than a high school education to over half of those with more than a high school education while poverty increased from over three fourths of female to 29 percent of householders in these groups .

The probabilities of living in poverty declined with employment 
most dramatically among those with higher schooling (Tables III, VI, VII). Low educated men and women are more prone to hold low paying jobs and be working poor as well as constrained by lack of employment. As already indicated, employed women remain more likely to be poor than men in each educational status. Even when still more likely to be poor, however, employment also reduced poverty substantially among both men and women with less education. Table III indicates that female householders with more than a high school education out of the labor force had poverty rates of 44 percent, compared to the previously-mentioned 15 percent among those employed. Around two thirds of women householders with a high school education out of the labor force were poor compared to 44 percent of those employed, while three fourths of women householders with lower education out of the labor force of lived under poverty compared to 54 percent of those who were employed. Poverty rates for unemployed female and more for male householders were even higher than those out of the labor force, suggesting that the latter may include persons who were not active in the labor market because they had access to other assets including Social Security or other benefits and family support.

The same pattern was found when considering marital status of householders without husband present. Table VII shows how the poverty rates of women householders in each of the marital statuses declined with education and with employment even in the lowest levels of education. Put in Safa's (1998:212) words: "In Puerto Rico...female heads of household continue to be the poorest of the poor, because most are unemployed and living alone."

\section{Making Ends Meet: Dealing with Poverty}

Even when female-headed families may be more likely to be poor in terms of income, however, Safa $(1998,1999)$ has been a pioneering author in questioning the assumption that female heads of family are deviant, pathological, or necessarily the "poorest of the poor." Chant (2007) has insisted that female-headed families are not more likely to suffer problematic social relations, conflicts in their childrearing, or to be trapped in lower socioeconomic strata transmitting poverty to their offspring. Moreover, she has contended that income is only one of the dimensions of poverty, to which we must add social dimensions such as the sense of capability, decision making, and empowerment. As we observed above, female heads of family may be and feel more capable and have greater access to their own resources-even with lower total family income- - than women who are subjected to male control and who benefit by only limited contributions from their husbands. They also 
tend to make better use of those resources, and direct them to the well being of children and other family members, so that their livelihood is not as deteriorated by lower income (see, e.g., Chant 2007). Concrete investigation and analyses must be undertaken to establish whether and in which conditions female family headship entails greater autonomy (Mohammed 1999).

It is still true, nonetheless, that in many countries female heads of family tend to have fewer resources and are more vulnerable to poverty than those headed by men. Furthermore, if female heads of household are able to overcome the conditions of greater income poverty, it is many times at the cost of greater inputs of paid and unpaid work, time, and effort. Chant (2007) coins the concept of "feminization of responsibility and obligation," to underscore that if in some cases women's income poverty may not actually be increasing, their duties for coping with economic constraints are growing, particularly when they are unable to negotiate greater income or unpaid domestic work from men. Female-headed families are more vulnerable to bear these deprivations and burdens, and in places like Puerto Rico these are accentuated by income poverty.

Even when accepting the possibility of women's greater autonomy with access to independent housing, Safa $(1998,1999,2005,2006)$ has stressed the possibility of resources and assets available to women heads of family when inserted in communal and extended family ties as a means of ameliorating their intensified work and material constraints. Support from family and kinship networks is indeed significant in enabling families, and particularly those headed by women, to overcome the conditions imposed by poverty. The possibility of access not only to assets accumulated during marriage, but the support of adult offspring and other relatives among widows or older divorced women, for example, could account for their lower poverty levels compared to unmarried householders. Our research on displaced workers showed that women with such access to family support were more capable of dealing with the economic and personal hardship coming with unemployment (Colón et al. 2008).

Our study also confirmed, however, Safa's findings that the extended family in Puerto Rico is no longer as available to share in moments of risk and crises (1993, 1995, 1998, 1999, 2005, 2006). Modernization, urbanization, migration, and social policies promoting the nuclear family and independent housing have tended to separate the extended family (Fernández Méndez 1964; Pérez de Jesús 1968, 1973; Hernández Álvarez 1964; Colón Warren 2002, 2003). Among the displaced workers we interviewed, help was in most cases limited to older children:

Mis hijas me traen cositas, no regular... Yo no voy a pedirle a nadie... Nadie

está por nadie más que los hijos. 
[My daughters bring me some things, but not regularly... I am not going to ask anything from anyone... Nobody is there for you except your children.] (Colón et al. 2008)

And given modernizing ideologies, even support from children was not expected as an obligation, as they were raised to assume only their own expenses and those of their own household:

Mi hija me ayudará en algo, pero ella no estudió y trabajó para los gastos míos... (y) ya mismo ella se me va, ella va a tener su casa propia.

[My daughter may help out in something, but she did not study and work to assume my expenses... and she is leaving soon, she is going to have her own household.] (Colón et al. 2008).

Most importantly, we must consider that economic constraints may themselves be impelling "declining networks of care" (Rochelle 1997) among families in lower socioeconomic status. Exchange of goods and services is restrained in this situation, and family relations may become more encloistered when one is left without the means to share goods, services, and support. As two displaced workers commented:

Pero como la familia también tiene sus problemas y sus cosas, no es mucho lo que pueden ayudar..

[But as the family also have their problems and their things, what they can offer is not much...]

Como están las cosas hoy en día, la familia de uno apenas tienen.. Aunque quieran ayudar a uno no pueden... la situación no lo permite.

[The way things are today, the family hardly has anything... They cannot help even if they want to... the situation does not allow it.] (Colón et al. 2008)

In this sense, González de la Rocha (2001), well known for her discussions on the "resources of poverty," has warned that neoliberal policies and economic crises are destroying diverse forms of economic activity providing for the sharing of livelihoods and are moving our societies towards the "poverty of resources."

The dwindling of resources in Puerto Rico also includes other means of supporting livelihood among the poor. Particularly, since the 1970s, poverty had been ameliorated by Social Security and pensions among working families, United States federal public benefits among lower income families, state employment, and a large but unmeasured informal economy (Dietz 2003; Sotomayor 1998). Contrary to the legitimacy and generally higher benefits of Social Security and pensions, considered as a right and retribution for services rendered, programs of public assistance directed at poor communities are stigmatized and limited as providing free subsistence in the best cases to a population incapable to provide 
for themselves - in the worst cases, undeserving and living off tax payers' money (Hernández Angueira 2001). With greater probability of one or more earners, class and gender biases in access to these programs have tended to allocate male-headed and married couple families to the Social Security programs while, given their employment history, female-headed families living under poverty have tended to depend more on public assistance, including food stamps (Colón Warren 2006; Hernández Angueira 2001).

Under this restricted and dual system of federal payments, access to public benefits has maintained women in an unequal status, dependent on the state, and still under conditions of poverty. As Safa (1995, 1998, $1999,2005,2006)$ has contended, many women may in fact be more isolated from male partners, kin, and community in their response to economic responsibilities and more dependent on public patriarchy. Public benefits have, nonetheless, been crucial for the subsistence of lower income women and particularly female heads of family and have provided them with some resources for more independent living and resistance relative to men and to more hierarchical family relations.

It is therefore indeed worrying that, even before the most intense effects of welfare reform, the proportion of poor married couple families receiving public assistance declined from 46 percent to 30 percent between 1990 and 2000 and close to half did not receive either such public benefits or Social Security. The plight of poor female-headed families was even harder, as the proportion receiving public assistance declined from 61 percent to 47 percent over this period (Colón Warren 2006). The more recent decline in employment places even higher educated women and men on the verge of poverty and state dependence at the same time that it reduces government jobs providing social services that have been crucial in the subsistence of lower income families.

\section{Some Conclusions}

Without being the only factor, economic trends promoting women's employment and extending their social participation have broadened their dimensions of autonomy and transformed the definition of female roles to include the expectation of their economic contribution. The challenge to the "myth of the male breadwinner" (Safa 1995) has provided for the acceptance of dual earner families and democratizing marital relations. Intensified by declining male employment it has also provided for marital dissolution and the expansion of female-headed households without husbands among women resisting marriage, as well as renegotiations in the provider role with joint or de facto female household heads and householders even among married women. 
Increasing lack of jobs for men and women may not only expand poverty among married couples, but intensify marital conflict, while setting back advances in women's autonomy, gender equity, and renegotiations of the provider role. Women may become female heads facing even greater economic insecurity, intensifying the work, efforts and time required to meet their families' subsistence needs. We must also underscore that economic constraints may also reproduce housewifery and undermine women's resistance to violence and subjection, forcing them to remain in unsatisfactory relations as they increase their dependency. If economic pressures may undermine marital stability among lower income couples, the enforced dependency may also be more prevalent in lower socioeconomic strata, particularly with reduced access to public assistance. The proportion of female heads of household under poverty may actually appear lower to the extent that it is higher-educated women who have the resources and become householders, without reducing the needs and burdens of low income women and female heads of family. With recent developments reducing employment among highereducated men and women, however, even married couples and female householders of higher socioeconomic strata are placed on the verge of poverty - thus increasing the obligations faced by women.

González de la Rocha (2001) has analyzed how, under the prevailing economic regimes, some form of remunerated work and employment has ultimately been required to provide for the diverse strategies of survival among poor community and family members. We have observed that access to the resources provided by at least one earner has been necessary, if not sufficient, to surpass income poverty. Married couple families, with more earners, widows, with access to their husbands' and family accumulated assets, ultimately depending on their employment history, and divorced and unmarried women's own earnings, are correlated with the reduced probability of poverty-even when it may also be ameliorated by support from kinship networks. Promoting women's employment appears crucial, not only in terms of their full social participation and gender equity, but as a means of the reduction of poverty, both as dual earners in married couple families and particularly among female heads of family who bear alone their household's material and social responsibilities.

Yet, women's work must still be understood in the context of relations of social and gender equity. Men's unemployment may not only mediate marital conflict, but it also robs couples and families of their earnings and input. As Safa (1995:183) suggests: "Women gain little from increased employment if they are merely substituting their earnings for those of men." This is because, as she adds, "While this form of economic restructuring may challenge the myth of the male breadwin- 
ner, it also shifts the burden of family survival from men to women." We must remember as well that it is a shift embedded in female definitions as mothers that make women responsible for their families' well being, including caring and domestic work; definitions as mothers which leave them as heads of family under conditions of marital dissolution and lone motherhood. It is a definition that still subjects them primarily to the domestic sphere, even when they do not live with a male partner, and that in a myriad of ways also places women in an unequal status in the labor market and the public sphere-the situation of public patriarchy. The shift is then to the double burden of a labor market offering lower pay and more domestic work to make ends meet and fulfill family obligations.

Not only to provide for men's and women's greater autonomy, but even for the mutual exchange that may facilitate marital stability and solidify kinship and community networks, we should consider policies promoting the broader and more equitable distribution of employment, social services, time, and resources as the way to reduce poverty and socioeconomic inequality. Promoting women's employment must be accompanied by more adequate pay in the jobs they fill and their access to higher rank positions, but also the expansion of the personal and social services and redistribution with men of domestic responsibilities that enable the more equitable distributions of work, time for recreation, resources and ultimately, satisfactory social relations.

\section{Notes}

1 Excerpts were reproduced from a total of 47 semi-structured interviews, 31 to displaced workers from a tuna processing plant which closed in 2001 and 16 to workers displaced from a clothing factory that closed in 2002. Only ten of the displaced workers were under 40 years old, 27 were presently married and most of the rest were householders either through divorce, widowhood, or never marrying. Twenty had not completed High School, 14 had a High School degree and 13 had at least some university education, although only a few were not employed in production work. Among displaced women from the clothing factory we found a higher proportion of women younger than 40 years old ( 6 cases), who were more likely to have at least some university education ( 4 cases) and to be presently married (4 cases).

2 Throughout a trajectory of slavery and the plantation system, Black women in the non Hispanic Caribbean were workers alongside men in the fields and services. With later laws that provided women with access to land, and an ideology linking family economic support 
to maternal responsibility, non Hispanic Afro Caribbean females have historically shared greater economic autonomy than in other Regions, albeit still in an unequal status in the labor market and economic sphere. Afro Caribbean men's economic contribution and control of women's work, on the other hand, has tended to be more limited and unstable. A social and cultural pattern of a high prevalence of female headed households, common-law and visiting unions, and high rates of children born out of legal marriages has evolved, more frequent among the lower class Afro Caribbean populations, along with the normatively sanctioned legal married couple families. Although it is difficult to provide precise measures of prevailing household structures, studies since the mid twentieth century have suggested that female headed families surpassed since then over one third of households in many countries of the Region. The pattern is not shared by East Indian Caribbean populations, who have shown a higher prevalence of male headed nuclear families and less economic autonomy among women (See essays in Momsen, 1993; Barrow, 1999, 1996; Trotz, 2002).

There has been extensive research and discussion as to the factors impinging on these patterns of Afro Caribbean family structurestheir origins in African culture or slavery, to what extent they constitute social pathology or functional adaptations to economic constraints on men being economic providers, what constitutes a labeled matrifocal system, and whether it entails male marginality. Further investigation and analyses are still warranted on many of these issues (Barrow, 1996, 1999; Brereton, 1999; Mohammed, 1999). In any case, there is evidence of a pattern in which childbearing and motherhood are not linked to legal marriage and in which marriage is less frequent. Marriage may actually be considered a greater responsibility and a constraint to women's autonomy, compared to visiting unions and female headed or centered households. Female, mother- centered consanguineal ties are strengthened relative to the conjugal bond, providing childrearing and material support among women, although men may also be providers even when not living with their children's mother, as well as in their roles as sons or brothers (See essays in Momsen, 1993; Barrow, 1999, 1996; Mohammed, 1999; Rowley, 2002). This does not mean that women or female heads of family do not suffer gender subordination or that there is an inversion of power relations between men and women. Momsen has coined the terms "double paradox" and "patriarchy in absence" to describe a pattern in which women have comparatively greater economic autonomy and control in the domestic domain than in 
other Regions, while men still hold the greatest control, power and resources at broader political, social and economic levels. If women centered kinship ties may provide them with support and access to economic activity, women are still concentrated in lower paid work, limiting their household income. Moreover, not all female heads are embedded in such kinship networks, making female heads even more vulnerable to poverty (See essays in Momsem, 1993 and Mohammed 2002; Barrow, 1996; Bolles, 1985; Lindsay, 2002; Mohammed, 1999).

\section{References}

Brameld, Theodore. 1959. The Remaking of a Culture: Life and Education in Puerto Rico. New York: Harper and Row.

Barrow, Christine. 1999. "Men, Women and Family in the Caribbean: A Review." Pp. 119-135 in Gender in Caribbean Development, $2^{\text {nd }}$ edition, edited by Patricia Mohammed and Catherine Shepherd. Barbados, Jamaica, Trinidad Tobago: Canoe Press UWI.

1996. Family in the Caribbean. Themes and Perspectives. Kingston: Ian Randle Publishers, Oxford: James Currey Publishers.

Bolles, Lynn A. 1985. "Economic Crises and Female Headed Households in Urban Jamaica." Pp. 53-64 in Women and Change in Latin America, edited by June Nash and Helen Safa. South Hadley, MA: Bergin \& Harvey Publishers, Inc.

Brereton, Bridget. 1999. "General Problems and Issues in Studying the History of Women." Pp. 119-135 in Gender in Caribbean Development, $2^{\text {nd }}$ edition, edited by Patricia Mohammed and Catherine Shepherd. Barbados, Jamaica, Trinidad Tobago: Canoe Press UWI.

Bureau of Labor Statistics, Department of Labor and Human Resources, The Commonwealth of Puerto Rico. 2007. Serie histórica de empleo y desempleo: Promedios años naturales, 1970-2006.

Bureau of Labor Statistics, Department of Labor and Human Resources, The Commonwealth of Puerto Rico. 2009. Employment and Unemployment, Puerto Rico, Average Calendar Year, 2009.

Chant, Sylvia. 2007. Gender, Generations and Poverty: Exploring the Feminisation of Poverty in Africa, Asia and Latin America. Cheltenham, UK: Edward Elgar Publishing Ltd.

Colón Warren, Alice. 1998. "The Feminization of Poverty among Women in Puerto Rico and Puerto Rican Women in the Middle Atlantic Region of the United States." Brown Journal of World Affairs 5(2):263-282.

2002. "Asuntos de género en la discusión pública a través del siglo veinte en Puerto Rico." Revista Jurídica de la Universidad Interamericana de Puerto Rico 36(3):403-432.

2003. "Mujeres, familias y trabajos en Puerto Rico: discusiones 
en la investigación social."Revista de Ciencias Sociales 12 (Nueva Época): 68-101.

2006. "Incremento en las mujeres jefas de familia y feminización de la pobreza en Puerto Rico.” Plerus 23-24:78-96.

Colón, Alice, María M. Mulero, Luis Santiago and Nilsa Burgos. 2008. Estirando el peso: acciones de ajuste y relaciones de género ante el cierre de fábricas en Puerto Rico. Río Piedras: Centro de Investigaciones Sociales, Universidad de Puerto Rico.

Crespo, Elizabeth. 1994. "Puerto Rican Women: Migration and Changes in Gender Roles." Pp. 137-150 in Migration and Identity, edited by Rina Benmanyor and Andor Skontes. New York: Oxford University Press.

De Roca, Angelina. 1963. "Algunos valores prevalecientes en la sociedad puertorriqueña." Revista de Ciencias Sociales 7(1-2):121-140 .

Dietz, James L. 2003. Puerto Rico: Negotiating Development. Boulder, CO: Lynne Rienner Publishers.

Fernández Méndez, Eugenio. 1964. "Algunos cambios culturales, económicos y sociales que afectan la familia en Puerto Rico." Revista de Ciencias Sociales 8(2):167-172.

González de la Rocha, Mercedes.2001. "From the Resources of Poverty to the Poverty of Resources?" Latin American Perspectives 28(4):72-100.

Hernández Álvarez, José. 1964. "Una revisión de Cañamelar después de diez años." Revista de Ciencias Sociales 8 (2):143-158.

Hernández Angueira, Luisa. 2001. Mujeres puertorriqueñas, "welfare” y globalización. San Juan: Publicaciones Puertorriqueñas.

Junta de Planificación, Oficina de la Gobernadora, Estado Libre Asociado de Puerto Rico. 2000. Informe Económico a la Gobernadora. Septiembre.

Lindsay, Keisha. 2002. "Is the Caribbean Male an Endangered Species?" Pp. 56-82 in Gendered Realities. Essays in Caribbean Feminist Thought, edited by Patricia Mohammed. Mona, Kingston, Jamaica: Centre for Gender and Development Studies and The University of West Indies Press.

Mohammed, Patricia. 2002. Gendered Realities. Essays in Caribbean Feminist Thought. Mona, Kingston, Jamaica: Centre for Gender and Development Studies and The University of West Indies Press.

1999. "The Caribbean Family Revisited". Pp. 164-175 in Gender in Caribbean Development, $2^{\text {nd }}$ edition, edited by Patricia Mohammed and Catherine Shepherd. Barbados, Jamaica, Trinidad Tobago: Canoe Press UWI.

Momsen, Janet. 1993. Women and Change in the Caribbean. A Pan-Caribbean Perspective. Kingston: Ian Randle, Bloomington and Indianapolis: Indiana University Press, London: James Currey.

2002. "The Double Paradox". Pp. 44-55 in Gendered Realities. Essays in Caribbean Feminist Thought, edited by Patricia Mohammed. Mona, Kingston, Jamaica: Centre for Gender and Development Studies and The 
University of West Indies Press.

Muñoz Vázquez, Marya and Edwin Fernández Bauzó. 1988. El divorcio en la sociedad puertorriqueña. Río Piedras: Huracán.

Pérez de Jesús, Manuel. 1968. "Desarrollo económico, crecimiento poblacional y el bienestar social en Puerto Rico." Revista de Ciencias Sociales 12(1):23-52.

Pérez de Jesús, Manuel. 1973. "El desarrollo económico, la sobrepoblación y la desigualdad en Puerto Rico." Revista de Ciencias Sociales 17(2):167-214.

Pérez Herrans, Carmen A. 1996. "Our Two Full-Time Jobs: Women Garment Workers Balance Factory and Domestic Demands.” Pp. 139-160 in Puerto Rican Women and Work: Bridges in Transnational Labor, edited by Altagracia Ortiz. Philadelphia: Temple University Press.

Reynolds, Lloyd G. and Peter Gregory.1965. Wages, Productivity and Industrialization in Puerto Rico. Homewwod, IL: R.D. Irwin.

Román, Madeline and María M. López. 1987. "La hormiga alada o en torno al proyecto feminista socialista: reprivatización y mercantilización del contexto doméstico y la instancia de la subjetividad." Homines 4:137-153.

Roschelle, Anne R. 1997. "Declining Networks of Care: Ethnicity, Migration, and Poverty in a Puerto Rican Community." Race, Gender, and Class 4(2):107-116.

Rowly, Michelle. 2002. "Reconceptualizing Voice: The Role of Matrifocality in Shaping Theories and Caribbean Voices." Pp. 22-43 in Gendered Realities. Essays in Caribbean Feminist Thought, edited by Patricia Mohammed. Mona, Kingston, Jamaica: Centre for Gender and Development Studies and The University of West Indies Press.

Safa, Helen I. 1974. The Urban Poor of Puerto Rico: A Study in Development and Inequality. New York: Holt, Rinehart, and Winston.

. 1993. "Las mujeres y la industrialización en el Caribe: una comparación de Puerto Rico y República Dominicana.” Pp. 263-318 in Género y trabajo: la industria de la aguja en Puerto Rico y el caribe hispano, edited by María del C. Baerga. San Juan: Editorial de la Universidad de Puerto Rico. 1995. The Myth of the Male Breadwinner: Women and Industrialization in the Caribbean. Boulder, CO: Westview Press.

1998. "Female Headed Households in the Caribbean: Sign of Pathology or Alternative Form of Family Organization?" Brown Journal of World Affairs 5(2):203-214.

1999. "Female Headed Households in the Caribbean: Deviant or Alternative Form of Household Organization?" Latino(a) Research Review 4(2):16-26 .

. 2005. "The Matrifocal Family and Patriarchal Ideology in Cuba and the Caribbean." Journal of Latin America Anthropology 10(2):314-338.

. 2006. "Globalización, desigualdad e incremento de los hogares encabezados por mujeres." Pp. 107-124 in De lo privado a lo público: 30 años de lucha ciudadana de las mujeres en América Latina, edited by Nathalie 
Women's Employment and Changing Gender Relations...

Lebon and Elizabeth Maier. Mexico City: Siglo XXI/UNIFEM/LASA.

Sotomayor, Orlando. 1998. Poverty and Income Inequality in Puerto Rico, 19701990. Río Piedras: Centro de Investigaciones Sociales, Universidad de Puerto Rico.

2002. "La pobreza en Puerto Rico.” Pp. 1-18 in Ensayos sobre la pobreza en Puerto Rico, edited by Francisco Martínez and Francisco Catalá. San Juan: Publicaciones Puertorriqueñas.

Steward, Julian, et al. 1956. The People of Puerto Rico: A Study in Social Anthropology. Urbana: University of Illinois Press.

Stycos, J. Mayone. 1955. Family and Fertility in Puerto Rico: A Study of the Lower Income Group. New York: Columbia University Press.

Trotz, Elissa. 2002. "Gender, Ethnicity and Familial Ideology in Georgetown, Guyana. Household Structure and Female Labour Force Participation Reconsidered.” Pp. 249-276 in Gendered Realities. Essays in Caribbean Feminist Thought, edited by Patricia Mohammed. Mona, Kingston, Jamaica: Centre for Gender and Development Studies and The University of West Indies Press.

Tumin, Melvin and Arnold Feldman. 1961. Social Class and Social Change in Puerto Rico. Princeton, NJ: Princeton University Press.

United States Bureau of the Census. 2005-2007. Puerto Rico Community Survey. Public Use Micro Sample (PUMS).

United States Bureau of the Census. 2006-2008. Puerto Rico Community Survey. 